This is an electronic reprint of the original article. This reprint may differ from the original in pagination and typographic detail.

Author(s): Leppäniemi, Matti; Jayawardhena, Chanaka; Karjaluoto, Heikki; Harness, David

Title: Unlocking behaviors of long-term service consumers : the role of action inertia

Year: $\quad 2017$

Version:

Please cite the original version:

Leppäniemi, M., Jayawardhena, C., Karjaluoto, H., \& Harness, D. (2017). Unlocking behaviors of long-term service consumers : the role of action inertia. Journal of Service Theory and Practice, 27(1), 270-291. https://doi.org/10.1108/JSTP-06-20150127

All material supplied via JYX is protected by copyright and other intellectual property rights, and duplication or sale of all or part of any of the repository collections is not permitted, except that material may be duplicated by you for your research use or educational purposes in electronic or print form. You must obtain permission for any other use. Electronic or print copies may not be offered, whether for sale or otherwise to anyone who is not an authorised user. 


\title{
Unlocking behaviors of long term service consumers: The role of action inertia
}

\begin{abstract}
Purpose - The purpose of this study is to examine the antecedents of word-of-mouth (WOM) in long term service settings. Specifically, we examine the moderating role of action inertia in the relationships between satisfaction and repatronage intention, satisfaction and WOM and repatronage intention and WOM.
\end{abstract}

Design/methodology/approach - The proposed model was empirically tested using survey data from 1,385 telecommunications service subscribers. The data were analyzed using partial least squares path modeling.

Findings - Results suggest that 1) a positive link between repatronage intention and WOM, hereto a neglected relationship in the marketing literature, 2) in contrast to previous literature, the behaviors of long term customers are not predictable, and 3) action inertia strengthens satisfaction - WOM and repatronage intention - WOM links and weakens satisfaction repatronage intention link.

Research limitations/implications - This study examines customers of a utilitarian service. To further determine the potential of our model, it is desirable to explore the validity of the model in other service settings, particularly those with high hedonic values.

Practical implications - The study provides valuable insights into repatronage intention -WOM link, with particular emphasis on the measurement and analysis of action inertia. This is important in understanding and evaluating inertia influences and identification of the drivers of WOM. These insights can be used by managers to better allocate their resources when investing in customer loyalty building exercises and in generating WOM.

Originality/value - This paper contributes to the literature in three main ways. Firstly, it examines the nuances of customer loyalty in continuous service contexts. Secondly, the study empirically tests the role of repatronage intention as an antecedent of WOM. Thirdly, the study introduces and tests the moderating role of action inertia on positive WOM.

Keywords: Service quality, Perceived value, Satisfaction, Repatronage intentions, Word-ofmouth, Action inertia

Article Classification: Research paper 


\section{Introduction}

With the decline in in traditional advertising, organizations are re-visiting the positive effects of WOM as a marketing tool (Sweeney et al., 2012). This enhanced practitioner interest has been matched by an increase in academic inquiries in WOM (for e.g. Jayawardhena et al., 2016). Research (for e.g. Ranaweera and Jayawardhena, 2014) indicates that the antecedent effects and consequences of positive WOM (Arndt, 1967; Keiningham et al., 2007; Zeithaml et al., 1996) are perhaps more nuanced than perceived wisdom suggests. Confusion also surrounds how loyalty, repatronage and positive WOM are measured. A large proportion of published studies measure loyalty through a combination of repatronage intention and positive WOM. Although repatronage intention and positive WOM are related, the inclusion of WOM, as a measure of customer loyalty, contradicts with both theoretical foundations (Dick and Basu, 1994) and empirical evidence (de Matos and Rossi, 2008; Söderlund, 2006; Watson et al., 2015). Given the above, this study examines positive WOM in continuous service settings. It furthermore treats positive WOM as 1) a focal construct, and 2) a consequence of repatronage intentions. We therefore respond to a specific call by Mazzarol et al. (2007, p. 1478), who state that "little research, however, has addressed antecedents of WOM when considering WOM as a focal construct."

In continuous service settings it has been observed that consumers display vastly different positive WOM behavior in spite of similar patronage intentions (Sabharwal et al., 2010). We suggest action inertia may explain this observation. Oliver (1999) suggested that "inertia" was a deeply held commitment to repatronize a preferred service provider (readiness to act attitudinal) and as active by ignoring competing offers (overcoming obstacles - behavioral) (Evanschitzky and Wunderlich, 2006; Oliver, 1999). Therefore, action inertia requires that there 
is both an attitudinal and behavioral component for it to exist. This indicates that the likely antecedents of WOM between those customers who are merely habitually loyal (behavioral component) and those whose loyalty is built merely on an emotional attachment (attitudinal component) to the service will differ. So whilst the outcome on repatronage activity will be similar, the impact on providing positive WOM may differ. Thus amongst the emotionally attached the effect on WOM is stronger (de Matos and Rossi, 2008). Given the potential implications for marketing research and practice, it is surprising that this view has not been widely embraced in previous studies.

The objectives of this paper are therefore, first, to examine the antecedent role of service evaluation constructs and loyalty on positive WOM, and second, to examine how these relationships may change with action inertia. To reiterate, our research is centered on continuous service settings. These customers, we suggest, have deeper knowledge of the service consumed, which has been gained over a number of years, consequently we would expect their WOM to command greater salience. The evidence indicates that the amount of time a consumer spends in a relationship with a supplier impacts WOM generation (Wirtz and Chew, 2002). Given that such services are highly intangible it makes it difficult for prospective customer to easily evaluate an offering. Getting action inert users to provide positive WOM has clear marketing benefits for the organization.

The remainder of this paper is structured as follows. The following section will provide background information on the constructs under examination. In this section, we will formulate hypotheses and present a conceptual model. The research methodology will then be detailed. The third section presents the analysis and results. Finally, the paper will conclude with a discussion 
of study outcomes and their implications for academics and practitioners, limitations of the study, and future research directions.

\section{Literature review}

Oliver (1999) defines loyalty as "a deeply held commitment to rebuy or repatronize a preferred product/service consistently in the future, thereby causing repetitive same-brand or same-brand-set purchasing, despite situational influences and marketing efforts having the potential to cause switching behavior" (p. 34). According to his framework, the various stages of loyalty occur in a progressive manner, with action loyalty the ultimate developmental stage of customer loyalty. Customers at the action loyalty phase experience action inertia and have the desire to maintain the highest level of customer loyalty. Researchers have described inertia as a customer's attitudinal propensity to maintain relationship with the company out of passiveness or inaction (Bawa, 1990; Lee and Neale, 2012; Zeelenberg and Pieters, 2004). Hennig-Thurau and Klee (1997) suggest that high levels of inertia reflect a stable relationship that is built on trust and commitment.

Inertia is often considered as a habit. According to Liu-Thompkins and Tam (2013, p. 22) habit is defined as "a behavioral disposition that is exercised frequently and in which responses are triggered directly by contextual cues." Action inertia, however, differs from habitual inertia. In part, this is because they are formed differently. Habit is developed through associative learning in which behavioral repetition and stable context induce the automaticity of behavior (Duhigg, 2012; Lally et al., 2010; Liu-Thompkins and Tam, 2013; Wood and Neal, 2009). A habitual attachment is to a large extent unemotional, indifferent, and convenience driven (Gounaris and Stathakopoulos, 2004; Lee and Cunningham, 2001; White and Yanamandram, 
2004). Habits are performed without evaluations, intentions, and goals (Ji Song and Wood, 2007; Tam et al., 2009). Therefore, repeat purchases and consumption driven by habit tend to be more rigid and will only occur when contextual cues, such as time and location, are present (Ji Song and Wood, 2007; Liu-Thompkins and Tam, 2013). Instead, action inertia builds in part on favorable attitudes (i.e. a deeply hold commitment to repatronage a preferred service provider). Attitudes can be explicit and implicit (Gawronski and Bodenhausen, 2006; Greenwald and Banaji, 1995; Wilson et al., 2000). We suggest that action inertia represents mainly an implicit form of attitudes which involves an automatically activated evaluation.

Loyalty is considered to consist of an attitudinal and a behavioral component (Kumar et al., 2013; Uncles et al., 2003). Attitudinal loyalty can be expressed both as the likelihood to recommend, and the likelihood to repurchase/repatronage (see Kumar et al., 2013 for a detailed review). Instead, behavioral loyalty can be considered in terms of customer retention, lifetime duration, usage, share of wallet, and cross buying (Bolton, 1998; Bolton and Lemon, 1999; Cooil et al., 2007; Gustafsson et al., 2005; Ittner and Larcker, 1998; Mittal and Kamakura, 2001; Seiders et al., 2005). This study adopts the loyalty intentions (i.e. repatronage and recommend intention) perspective rather than a behavioral or repeat purchase perspective. This allows us to avoid confusing habitually loyal customers (i.e. spurious loyalty) with customers who exhibit "true" loyalty (Dick and Basu, 1994), and whose loyalty is potentially driven by action inertia (Oliver, 1999).

In terms of loyalty intentions, prior research often treats repurchase intention and recommend intention (WOM) as components of loyalty and not as two distinct constructs (see Boulding et al., 1993; Brady et al., 2002; Dabholkar et al., 2000; Faullant et al., 2008; Sirdeshmukh et al., 2002; Zeithaml et al., 1996). However, recent meta-analyses of loyalty have 
questioned this "cocktail approach" (Söderlund 2006, p. 78). Based on their analyses, both de Matos and Rossi (2008) and Watson et al. (2015) support the argument that repurchase intention and WOM should be considered as separate constructs and a unidimensional approach should be avoided. In the line with de Matos and Rossi (2008) and Watson et al. (2015), the present study treats customer loyalty intentions as distinct constructs. In the current study, repatronage intention refers to a customer's intent to stay with a company (Zeithaml et al., 1996) and their overall attachment or deep commitment to a company (Oliver, 1999). Recommend intention (WOM) is defined as customer's likelihood to recommend and say positive things about company X to others (Zeithaml et al., 1996).

\section{Conceptual model and research hypotheses}

Figure 1 presents the framework of this study. Based on Oliver's (1999) cognitiveaffective-conative loyalty framework, this conceptual model argues that to understand how loyalty emerges requires careful assessment of consumers' cognitive evaluations of a brand, affective preferences for the particular brand, and conative or behavioral intentions to buy the brand. Specifically, customer satisfaction, perceived value, and service quality are postulated to lead to repatronage intention, which in turn are posited to have direct effects on positive WOM. Given the strong theoretical and empirical support for the relationships between service quality and perceived value (Cronin et al., 2000; Sweeney et al., 1999) and service quality and customer satisfaction (Fornell et al., 1996; Juga et al., 2010; Oliver, 1993; Yen and Lu, 2008), perceived value and satisfaction (Babin and Kim, 2001; Caruana et al., 2000; Rust and Oliver, 1994), perceived value and repatronage intention (Pura, 2005; Yang and Peterson, 2004) and satisfaction and repatronage intention (Espejel et al., 2007; Garbarino and Johnson, 1999; Lin 
and $\mathrm{Wu}, 2011$; Shankar et al., 2003), the study does not advance specific hypothesis for these linkages, but rather provides a test of the model as an overall default hypothesis. The relationship between service quality and repatronage intention is not hypothesized. This is because prior research provides strong empirical evidence that satisfaction mediates the effect of service quality on repatronage intention (Caruana, 2002). The model serves as a platform for assessing WOM as a focal construct to investigate the relationships between WOM and its relevant antecedents, especially repatronage intention as well as examining the moderating effect of action inertia on WOM.

Figure 1 about here.

Service quality and WOM

From the seminal work of Parasuraman et al. (1988) leading to the formulation of the SERVQUAL model, and subsequent critiques (for e.g. Cronin and Taylor, 1992), ample research in marketing has extensively investigated service quality (Bolton and Drew, 1991; Brady and Robertson, 2001; Parasuraman et al., 1994). The weight of evidence points towards a conceptualization of service quality as a construct composed of five dimensions - tangibles, reliability, responsiveness, assurance and empathy, with perceptions-only measures being seen as more psychometrically robust (Brady et al., 2002; Cronin and Taylor, 1992; Dabholkar et al., 2000). Gaining credence is the notion that customers' perceptions of service quality influences behavioral responses (Sánchez-Pérez et al., 2007), specifically WOM (Hartline and Jones, 1996). That is to say that when a marketer delivers a high quality of service, particularly over several consumption experiences, customers are likely to behave in a favorable manner, which may include spreading positive WOM. Evidence of the positive relationship between service quality 
and positive WOM is noted (Harrison-Walker, 2001). For example, Bloemer et al., (1999) studied four different service industries (entertainment, fast food, supermarkets and health care) and found a positive relationship between service quality and positive WOM. Similarly, Boulding et al. (1993, p. 24) empirically demonstrated that "the greater customer's perceptions of a firm's overall service quality, the more likely the customers are to engage in behaviors beneficial to the strategic health of the firm (e.g. generate positive word-of-mouth, recommend the service, etc.)". On balance, this study advances the following:

H1. Customer perception of the service quality is positively related to positive WOM.

\section{Perceived value and WOM}

Value judgments have an effect on satisfaction and customer loyalty (c.f. Cronin et al., 2000). Zeithaml (1988, p.8) defines customer value as "the consumer's overall assessment of the utility of a product based on the perceptions of what is received and what is given". This "getversus-give" perspective builds on the early work of Dodds and Monroe (1985) which possesses the merit of simplicity, but fails to reflect the complexity of consumers' perceptions of value (Sweeney and Soutar, 2001). Perceived value combines utilitarian (price/value ratio, performance quality) and hedonic responses (including emotional and social aspects of value) in the consumption experience (e.g. Babin and Kim, 2001; Diep and Sweeney, 2008). When a marketer delivers desirable utilitarian benefits and elicits hedonic responses from their customers through consumption experiences over time, these customers will engage in positive WOM. This notion is in line with Hartline and Jones (1996), who argue that customer's perceptions of value have an important relationship to their behavioral responses, particularly WOM. Prior studies 
provide empirical evidence of the positive effect of perceived value on WOM in service settings (Durvasula et al., 2004; Gruen et al., 2006; McKee et al., 2006). A similar relationship should exist in continuous consumption settings. Therefore,

H2. Customer perceptions of perceived value are positively related to positive WOM.

\section{Satisfaction and WOM}

Customer satisfaction research distinguishes two types of evaluations: transaction-specific satisfaction and cumulative satisfaction (Johnson et al., 1995). Transaction-specific satisfaction is customers' evaluation of their experience with, and reactions to, a particular product transaction or service encounter. Thus, transaction-specific research focuses on satisfaction with a product or service on a given occasion or transaction, or over a limited period of time. In contrast, the cumulative approach defines satisfaction as a customer's overall experience overtime with a product or service provider (Johnson and Fornell, 1991). Customer satisfaction is a cumulative, global evaluation based on experience with a firm over time (Homburg et al., 2005; Seiders et al., 2005). While transaction-specific satisfaction may provide specific diagnostic information about a particular product or service encounter, cumulative satisfaction is a more fundamental indicator of the firm's past, current, and future performance (Rust and Oliver, 1994). Given that this study is conducted within the context of long term service consumption, it addresses cumulative satisfaction. Much of early research reports a positive and linear relationship between satisfaction and WOM (Brown et al., 2005; Ranaweera, 2007; Saha and Theingi, 2009; Verhoef et al., 2002; Wangenheim and Bayón, 2007). Therefore: 
H3. Customer satisfaction is positively related to positive WOM.

\section{Repatronage intention and WOM}

As alluded to earlier, the majority of past research has considered repatronage intentions and WOM intentions as a unidimensional construct of loyalty (c.f. Boulding et al., 1993; Brady and Robertson, 2001; Brady et al., 2002; Cronin et al., 2000; Dabholkar et al., 2000; Ganesh et al., 2000; Sirdeshmukh et al., 2002; Zeithaml et al., 1996). Exceptions to this aggregated approach include studies conducted by de Matos and Rossi (2008), Gruen et al. (2006), Jones and Reynolds (2006), Maxham and Netemeyer (2002), Sweeney et al. (2012), and Söderlund (2006). Consequently, there have been very few studies examining the unidirectional effect of repatronage intention on WOM (de Matos and Rossi, 2008). The exceptions include studies conducted by Carpenter and Fairhurst (2005), Gounaris and Stathakopoulos (2004), Reynolds and Arnold (2000), Sichtmann (2009), and de Matos and Rossi (2008). Specifically, in a metaanalysis, de Matos and Rossi (2008) found that loyalty is significantly positively correlated with WOM $(r=.39)$. Sichtmann's (2007) study set in a telecommunications service setting reported that the customer's intention to stay with an existing service provider was positively related to positive WOM. Gounaris and Stathakopoulos (2004) found support for a positive relationship between loyalty and WOM communication. Carpenter and Fairhurst's (2005) work in retail clothing noted the positive and significant relationship between loyalty and WOM communication. Whilst Reynolds and Arnold (2000), demonstrated that store loyalty, within retail clothing, positively related to positive WOM communication. Based on the above discussion, we expect that customers who are more loyal to a product, service, brand, or 
organization are more likely to spread positive WOM about this product, service, brand, or organization. This leads us to hypothesize that:

H4. Repatronage intention is positively related to positive WOM.

\section{The moderating effect of action inertia}

Oliver (1999) contends that the various stages of loyalty (cognitive-affective-conativeaction) occur in a progressive manner, with action loyalty, the ultimate developmental stage of customer loyalty. Customers at the action loyalty stage experience action inertia and have the desire to maintain the highest level of loyalty. Thus, action inertia is expected to involve a strong attitude that "will endure, will resist attempts in contrary directions, will exert influence on the formation of related perceptions and beliefs, and will predict behavioral decisions with the highest fidelity" (Converse, 1995, p. ix). In contrast to this view, research often describes inertia as a habitual behavior (Anderson and Srinivasan, 2003; Liu-Thompkins and Tam, 2013; Rust et al., 2004) and as passive service patronage without true loyalty (Huang and Yu, 1999; White and Yanamandram, 2004). Habit is often interpreted as the multiplication of behavioral stability and action frequency (Ji Song and Wood, 2007; Wood et al., 2005).

Prior research has examined the relationship between inertia and customer loyalty, with most studies demonstrating positive effects of inertia on customer loyalty (Vogel et al., 2008; Wu, 2011; Yanamandram and White, 2006). Effects of inertia on the relationship between satisfaction and loyalty have also been examined, with mixed results. For example Anderson and Srinivasan (2003) and Han et al., (2011) report a significant positive effect, but Anderson and Swaminathan (2011) indicate a negative moderating effect. 
In continuous consumption settings, customers are involved in complex evaluations of service offerings. After forming a favorable service perception, customers discriminate among competing offerings and repatronize superior offerings. Because of a deeply held commitment to repatronage a preferred service provider action inertia makes the customer less interested in alternative offerings and less susceptible to the effects of dissatisfying service experiences. We therefore contend that increasing levels of inertia will reduce the sensitivity of satisfaction and repatronage intention links. In contrast, when there has been less of an opportunity for inertia to develop, a customer's choice to leave or stay with their service provider is likely to be based on the level of satisfaction (service experience). We therefore wish to explore the notion that the relationship between satisfaction (service experience) and customer loyalty erodes away with increasing customer inertia. Consequently:

H5a. Action inertia weakens the positive relationship between satisfaction and repatronage intention.

As noted earlier, prior research suggest that loyalty leads to referrals, endorsements and positive WOM (Carpenter and Fairhurst, 2005; de Matos and Rossi, 2008; Gounaris and Stathakopoulos, 2004; Reynolds and Arnold, 2000; Sichtmann, 2009; Srinivasan et al., 2002). WOM commonly refers to the informal communications among consumers about product and services (Westbrook, 1987). Following Nyer and Gopinath (2005), we treat WOM as a public commitment which binds customers to their prior evaluations.

By engaging in WOM, customers adopt a public position that guides their behavior. For instance, after providing negative WOM, a customer may find it difficult to repatronize a particular service (Davidow, 2003). According to Garnefeld et al. (2013) the pressure to behave 
in a particular way, i.e. not to contradict recommendations (WOM) is consistent with a commitment. This is in line with the commitment-consistency principle which suggests that people who feel committed to a particular behavior, especially when the commitment is active, public, and freely chosen tend to behave consistently with that commitment (Aronson, 1992; Cialdini, 1993). As Cialdini, (1993) explains “once we make a choice or take a stand, we will encounter personal and interpersonal pressures to behave consistently with that commitment." (p. $51)$.

To date, little research exists on the effects of action inertia to satisfaction-WOM and repatronage intention-WOM links. When viewed through the principle of commitmentconsistency, strong action inertia suggests conditions for consumers to engage positively with WOM would exist. This is because the customer has made their choice and is both committed to a superior offering (internal consistency), and to appear consistent to others (external consistency). Thus, if action inertia is strong, the commitment-consistency principle would predict that both repatronage intention and satisfaction relate more strongly to WOM because of the expected gains in reputation, influence of others and commitment to the preferred offering. In contrast, when action inertia is weak, the customer has not yet taken a stand and social pressure drives them to make more effort to process information and evaluate alternative services to form a favorable attitude. Therefore, even satisfied and loyal customers are less likely to engage in positive WOM. Based on this discussion we wish to test the following hypothesis:

H5b. Action inertia strengthens the positive relationship between satisfaction and WOM. H5c. Action inertia strengthens the positive relationship between repatronage intention and WOM. 


\section{Control variables}

Customers' repatronage intention and WOM may also depend on individual and consumption characteristics (Yang and Peterson, 2004). With respect to individual characteristics, the model includes the effects of gender (Mittal and Kamakura, 2001), age (Homburg and Giering, 2001), and income (Seiders et al., 2005). Prior studies suggest that customers' consumption characteristics are important determinants of customer loyalty in consumer markets (Rust et al., 2004; Vogel et al., 2008). Thus, the effects of relationship length (Verhoef, 2003) and usage level (Bolton and Lemon, 1999) also serve as controls.

\section{Methodology}

Sample

To test the hypotheses, a survey of mobile telecommunication users in Finland was conducted. The competitive landscape in the Finnish telecom industry is intense but stable. Three telecom companies dominate the market. Because the mobile penetration rate in Finland is over $100 \%$ (many people own more than one mobile phone), systematic random sampling was used. The sampling frame contains all necessary information for selection purposes (e.g. personal identification, birth date, gender, marital status, citizenship, addresses). The sorting of sampling frame is based on the domicile code and thus yields implicit stratification according to geographical population density. The sample was drawn from the database of Finnish Population Register Centre. The majority of the respondents are in the 35-49 (31\%) and 50-64 (36\%) age groups, and the gender balance is reasonable (females 56\% and males $44 \%$ ). Thirty-five percent of respondents had been a customer of their current mobile operator for two to four years, and $31 \%$ for over four years. Forty-four per cent reported having a monthly mobile phone bill 
between $€ 21$ and $€ 40$ per month, while $40 \%$ reported a bill of less than $€ 20$ per month. All survey respondents had monthly-paid contracts.

In total, of 6,000 questionnaires, accompanied by a cover letter and a prepaid return envelope, were mailed. The cover letter explained the purpose of the study, assured confidentiality of data, and thanked the prospective participant for their assistance. To increase response rates, participation was encouraged by inclusion in a prize draw for a mobile phone. A total of 1,385 usable responses were received, for a response rate of $23.1 \%$. The sample mirrors well the Finnish adult population. Nonresponse bias was evaluated by a comparison of early respondents and late respondents, in accordance with Armstrong and Overton (1977) procedure. No significant differences (at $p<0.05$ ) were found on any of the constructs considered in the study and thus nonresponse bias does not appear to be a problem.

\section{Measures}

Several steps were taken to enhance the content validity of the measures. First, an intensive study of the relevant literature to identify valid measurements for the related constructs was conducted. Wherever possible, existing measures were adopted. Second, three managers (representing different mobile service providers) and four academics individually reviewed the questionnaire and assessed the suitability, readability, and ambiguity. The questionnaire was iteratively revised according to the feedback received. Third, a pilot test was conducted with 33 graduate students at a large university in Finland. The questionnaire was further revised on the basis of inputs from the pilot test.

Service quality is measured with an adapted version of Cronin and Taylor's (1992) 22-item scale (see also Harris and Goode, 2004). A directly assessed importance weight was needed for 
each attribute. However, because of the large number of attributes, weighted average SERVPERF score computation, as Cronin and Taylor proposed, was not an option. Thus, the respondents were asked to evaluate the importance of each attribute on a Likert scale anchored by 1 (not at all important) and 7 (extremely important). In line with the conceptualization of perceived value, the functional value element (price/value ratio, performance quality) was measured with the six items from Sweeney and Soutar's (2001) perceived value scale (PERVAL). The emotional value element was also adapted from the PERVAL scale. This measure consists of six items that assess the perceived value derived from the affective states that a service usage generates and services' ability to enhance one's social self-concept.

The five satisfaction measures come from the scales of Chiou et al. (2002), Cronin et al. (2000), and Harris and Goode (2004). The repatronage intentions scale is constructed to measure customers' intention to maintain the relationship with their current telecom service provider. The scale is adapted from the scales of Maxham and Netemeyer (2002) and Pritchard et al. (1999). In line with the advanced definition of WOM as customers' self-reported recommendation intention rather than their recommendation behavior, WOM is measured with a two-item scale (Zeithaml et al., 1996).

Action inertia is measured from an action control perspective (Kuhl and Beckmann, 1985), though recent studies appear biased towards switching costs or habitual behavior (i.e. behavioral stability and action frequency of consumers) (Anderson and Srinivasan, 2003; Colgate and Lang, 2001; Kuo et al., 2013; Vogel et al., 2008). In this regard, extant measures of inertia are not able to fully capture the meaning of action state of inertial rebuying in a way that Oliver $(1999, \mathrm{p} .36)$ conceives as an "action inertia". As detailed previously, the arguments and view of Oliver are both compelling and convincing. Thus, in line with Oliver, the three items that gauge action 
inertia serve to evaluate customers' commitment to re-buy a preferred service provider and to ignore competing offers (see Appendix A).

In addition, the study included five control variables: gender, age, income, relationship length and usage referring to monthly service consumption. Relationship length was measured by asking respondents to evaluate how long (in years) they have maintained relationships with their current telecom service provider? The monthly consumption construct was operationalized by asking, "How much is your average monthly bill for cellular services?" The survey was administered in Finnish. The questionnaire was professionally translated using back translation, which is a common form of proving the accuracy of translations in marketing studies.

The hypotheses were tested with SmartPLS 2.0 (Ringle et al., 2005). Our decision to use PLS is based on two primary considerations (see Hair et al., 2014, p. 19). First, PLS-SEM is recommended when the focus is on prediction as factor indeterminacy makes CB-SEM unsuitable for prediction purposes. Thus, our focus is on predicting the relationships between the target constructs and variance of the outcome variables. Second, PLS-SEM allows the estimation of complex models with many indicators, constructs, and structural model relationships to ensure convergence. In CB-SEM complex models often do not converge or produce improper results, particularly when the data is non-normal.

\section{Results}

Figure 2 depicts the structural model. All constructs draw on a reflective measurement model set-up (47 items in total). Service quality and perceived value are modeled as secondorder factors; all other constructs are first-order factors.

Figure 2 about here. 
Measurement model assessment

Convergent validity requires a factor loading greater than 0.70 and an average variance extracted (AVE) no less than 0.50 (Hair et al., 2014, p.103). As Appendix A shows, all standardized factor loadings were greater than the minimum acceptable level of 0.5 , and only one item had a loading lower than the preferred level of 0.7 (Bagozzi and Yi, 1988; Hair et al., 2006). The AVE values exceeded 0.50 , thus indicating convergent validity for all constructs. Composite reliabilities were also high (ranging from 0.87 to 0.96). Furthermore, the square root of the AVE of each construct is larger than its correlations with the other constructs (Hair et al., 2014, p.106), indicating discriminant validity. Table 1 shows the square root of the AVE and the inter-construct correlations.

Table 1 about here.

Podsakoff et al.'s (2003) proposed test examined the potential for common method bias. In line with Liang et al.'s (2007) recommendations, a common method factor test showed that that the average variance explained (AVE) by the indicators is 0.775 , whereas the average methodbased variance is 0.028 . These results indicate that common method bias is not a serious concern in the study.

\section{Structural model assessment}

The $R^{2}$ and $Q^{2}$ values provide support for the model's predictive accuracy. The literature suggests that $R^{2}$ values of $0.75,0.50$ and 0.25 may be considered substantial, moderate and weak, 
respectively (Hair et al., 2011; Henseler et al., 2009). The examination of the endogenous constructs' predictive power (Figure 2) shows that WOM, the primary outcome measure of the model, has a moderate $R^{2}$ value 0.467 . Prediction of repatronage intention is higher with an $R^{2}$ value of 0.505 . Satisfaction added the highest prediction power to the model with an $R^{2}$ value of 0.593 .

Figure 2 about here.

Another means to assess model's predictive relevance is the $Q^{2}$. According to Sarstedt $e t$ al. (2014) the $Q^{2}$ builds on the blindfolding procedure, which omits a part of the data matrix, estimates the model parameters and predicts the omitted part using the previously computed estimates. $Q^{2}$ values larger than zero for a particular endogenous construct indicate that the path model's predictive accuracy is acceptable for that particular construct (Sarstedt et al., 2014). Running the blindfolding procedure with an omission distance of seven yielded cross-validated redundancy values for all four endogenous constructs are well above zero (WOM: 0.422; repatronage intention: 0.402; satisfaction: 0.382 ), providing support for the model's predictive relevance.

To test the hypotheses, the direct and indirect relationships between the predictors and WOM were examined. As Figure 2 shows, service quality has no significant direct effect on WOM $(\beta=0.032, n s)$, suggesting rejection of H1. Further analysis on H1 showed that the relationship between service quality and WOM is more indirect (through perceived value, satisfaction, and repatronage intention) than direct. The total effect of service quality on WOM is slightly higher than the total effect of satisfaction on $\operatorname{WOM}(\beta=0.237, p<0.01$ vs. $\beta=0.206, p$ 
$<0.01$ ), underscoring the important role of service quality in driving WOM. The results provide support for $\mathrm{H} 2$ and $\mathrm{H} 3$; both perceived value and satisfaction are positively related to WOM, with path coefficients of $0.342(p<0.01)$ and $0.162(p<0.01)$, respectively. In support of $\mathrm{H} 4$, repatronage intention has a positive, though small, effect on $\operatorname{WOM}(\beta=0.089, p<0.01)$. With respect to the non-hypothesized relationships, we find that service quality is positively associated with perceived value $(\beta=0.356, p<0.01)$ and satisfaction $(\beta=0.114, p<0.01)$ and that perceived value has a positive effect on both satisfaction $(\beta=0.722, p<0.01)$ and repatronage intention $(\beta=0.213, p<0.01)$. The relationship between service quality and repatronage intention was not significant $(\beta=-0.027$, ns). Similarly to WOM, the effects of service quality on repatronage intention are indirect through perceived value and satisfaction.

Of the controls, only two of the effects are statistically significant $(p<0.01)$ : relationship age $\rightarrow$ repatronage intention $(\beta=0.157)$ and consumption level $\rightarrow \mathrm{WOM}(\beta=0.055)$.

To test H5a-H5c, a product indicator approach proposed by Kenny and Judd (1984) was employed. This is appropriate for partial least squares models with reflective scales (Henseler and Fassott, 2010). First, we find that the moderator action inertia is positively associated with the outcomes, repatronage intention $(\beta=0.172, p<0.01)$ and $\operatorname{WOM}(\beta=0.144, p<0.01)$. Second, the three moderating effects tested are all statistically significant. Specifically, action inertia weakens the link between satisfaction and repatronage intention $(-0.070, p<0.01)$ and strengthens the links between satisfaction and $\operatorname{WOM}(\beta=0.043, p<0.05)$ and repatronage intention and WOM $(\beta=0.057, p<0.01)$, in support of H5a, H5b and H5c.

\section{Discussion}

The study makes two important contributions to the loyalty literature. The first contribution pertains to WOM and its relationship to repatronage intentions. Following Sweeney et al. (2012) 
and Wien and Olsen (2012) we model repatronage intention and positive WOM as distinct constructs, and confirm that repatronage intention is an antecedent of positive WOM (de Matos and Rossi, 2008; Watson et al., 2015). When customers are loyal to a given provider, they are more likely to (1) give positive recommendations of the company to friends and relatives, (2) have greater motivation for processing new information about the company, and (3) have stronger resistance to being persuaded by conflicting information (Dick and Basu, 1994). These findings offer support to the separation of loyalty intentions into two distinct construct and provide a strong argument for modeling repatronage intention as an antecedent of positive WOM.

In a continuous service context, the present study illustrates that service quality has no direct effect on WOM. Service quality, does however, indirectly influence WOM through perceived value, satisfaction, and repatronage intention. Without value, satisfaction, and repatronage intention, service quality is an important but insufficient antecedent to generate positive WOM. The results provide evidence to the importance of service quality to WOM when complemented by two other service evaluation variables (value and satisfaction) and repatronage intention. This highlights the importance of perceived value and, and so corroborates other empirical evidence that identifies perceived value as an immediate antecedent in the prediction of WOM (Gruen et al., 2006; McKee et al., 2006). Thus the power of service quality to act as a service differentiator in certain circumstances is diminished. For example, infrastructure investment by mobile phone service suppliers combined with enhanced phone functionality, removes conditions that can diminished service quality. Thus for utilitarian type services, maintaining sufficient quality of service appears to be taken for granted by customers. 
The second objective of the study was to examine how these relationships may change with action inertia. This study illustrates the importance of action inertia, a construct that has received little attention in marketing literature. Through the examination of action inertia, this research reinforces that customer loyalty behaviors are complex, requiring a more nuanced explanation. Specifically, how loyal customers may react to an enhanced product and service offer from their suppliers is not entirely predictable. When action inertia is strong it desensitizes the relationship between satisfaction and repatronage intention i.e. customers desire to remain loyal is relatively more dominant than their perception of satisfaction. Such customers have reached a stage where they want to stay with their current service provider. This is in line with the commitmentconsistency principle, where expected reputation gains, and the influence of others support commitment development, provided that past service experience had been positive. Whereas, when action inertia is weaker, satisfaction based on service experience becomes more dominant. Weak action inertia indicates the customer has not made a commitment to the service provider, even though they may be satisfied and through continued usage of the offering could be viewed as loyal. Such customers may be more active in their search for information to support their continued use of the service or to identify alternative suppliers.

The holy grail of loyalty appears to be creating the ideal conditions for customers to develop inertia, and perhaps, more controversially, our findings appear to show that simple maintenance of these standards appears to be sufficient for customers to renew their subscription. The finding that service subscribers with longer relationships have stronger repatronage intentions and that those with higher levels of consumption are more likely to spread positive WOM adds weight to the benefits of maintaining on-going customer relationships. Action 
inertia therefore acts as tool to differentiate between genuinely loyal customers and those not so when in a long term consumption relationship with their service providers.

\section{Managerial implications}

This study provides several valuable insights for marketing practitioners. First, the study contributes new knowledge to customer loyalty behaviors, especially factors that lead to positive WOM. The results confirm that perceived service quality and value, satisfaction, and repatronage intentions positively influence WOM. This reinforces the need not only to deliberately manage each of the four constructs as separate entities but also to develop awareness within service provider organizations of how they support and influence one another. These insights can lead to better allocation of resources when investing in customer loyalty-building exercises and in generating WOM. The results suggest that managers should pay attention to the factors that influence customers' WOM activities but also consider the distinction between repatronage intention and WOM when attempting to fine-tune marketing and service efforts to ensure the generation of positive WOM. Thus, service providers should invest in programs that foster the

repatronage intention of existing customers to achieve higher retention rates and stimulate WOM to facilitate the acquisition of new customers. As Schmitt et al. (2011) note, such referred customers (1) have a higher contribution margin, (2) exhibit a higher retention rate, and (3) are more valuable in both the short and long run.

Second, the results suggest that action inertia plays an important role in generating WOM among service subscribers. However, action inertia potentially presents a conundrum for service providers. On the one hand, loyal customers may well continue to re-buy the service offering, providing revenue certainty and perhaps requiring less marketing spend to maintain. Indicating 
that a low-level maintenance of customer relationships may well be a viable business strategy. On the other hand, the supplier can actively manage customers through up-sell or cross-sales techniques in the hope that a stronger relationship will occur as well as a corresponding increase in income. Such active marketing may run the risk that customers will revert back to the cognitive stage and evaluate other firms' offerings, thus increasing the potential for switching or generating negative WOM. Therefore, identifying the numbers and types of customers who exist in an action-inert state should be a precursor before managers create activities to manage them. Furthermore, such strategies need to be created with full knowledge of the potential negative consequences that might result from their implementation. Consequently, service providers should establish instruments to identify action loyal customers and implement customer relationship-building strategies (e.g., loyalty programs) that reinforce their commitment to repatronage. Loyalty can be increased through offerings that bolster customers' overall value perceptions, including both functional and emotional aspects of value, and by signaling the superiority of benefits to those of main competitors.

Third, it is notable that service quality has no direct effect on positive WOM but has a direct and significant influence on both perceived value and satisfaction, which in turn influence WOM. Thus, consistent delivery of service quality based on an understanding of which dimensions are relatively important to the consumer, as well as of performance criteria (core and ancillary), is critical; while delivery might not generate positive WOM directly, failure may result in negative WOM. As the findings show, perceived value is the most significant antecedent of telecommunications service subscribers' positive WOM. Therefore, products and services offered to telecommunications service users, including calls, data, value-added services, messaging, and so on, should be priced competitively (functional elements) and appeal to the 
audience (hedonic elements). Service subscribers who perceive the service as reasonably priced and have received superior net value for their service usage are more likely to generate positive WOM. Therefore, attempts to stimulate positive WOM among existing customers should emphasize service quality and, more important, the superior value customers receive from their relationship with the provider.

\section{Research limitations and implications for future research}

Notwithstanding theoretical and practical contributions, we acknowledge limitations of this study. The use of cross-sectional data is noted as a limitation. The cross-sectional nature of the study along with the use of survey data allows for an understanding of directional relationships amongst the constructs but does not allow causal inferences. That said, the current findings do, however, shed new light on our understanding of the dynamics of loyalty behaviours.

We acknowledge the place of data collection, Finland, a country with one of the highest mobile phone penetration rates and mobile data usage in the world may be viewed as an extreme example, consequently, any generalization must be taken with caution and in a manner that respects the complexity of differences and similarities in a national context. Replication of the study in countries where telecommunications service usage patterns are different from those in Finland would be desirable. On a similar note, our findings would benefit from inquiries in other (continuous) service industry settings. For example, financial services would provide the opportunity to examine how very long term customer relationships (sometimes measured in the life length of the customer) impact the relationships identified in this study. Our study was undertaken in what can be considered as a utilitarian type of service. Yet, other services are based on higher levels of company - person face-to-face interactions, and perhaps underpinned 
by hedonistic purchasing motivations e.g. gym membership. It is useful to note that controlled experiments or a longitudinal design could enhance our understanding of certain relationships. Whilst our model contains a number of constructs and moderators, it would be useful to incorporate other factors that may exert an influence on a customer's willingness to provide positive WOM. Future studies could include a wider range of constructs thus broadening the scope of the model, and helping to distinguish associations between constructs both conceptually and empirically. For example, possible factors which may significantly influence positive WOM may include commitment, trust and switching barriers. The last research limitation pertains to the operationalization and measurement of action inertia. Specifically, the factor loading for the third item was relatively weak (0.667). We thus recommend that researchers further develop the operationalization of action research construct. In developing the measurement, it is suggested that qualitative studies are also encouraged. In addition, the joint analysis of action inertia, habit and loyalty deserves the attention of future research efforts, as a more in-depth understanding of the dynamics of these two constructs is beneficial. 


\section{References}

Anderson, R.E. and Srinivasan, S.S. (2003), "E-satisfaction and e-loyalty: A contingency framework", Psychology \& Marketing, Vol. 20 No. 2, pp. 123-138.

Anderson, R.E. and Swaminathan, S. (2011), "Customer satisfaction and loyalty in e-markets: A PLS path modeling approach", Journal of Marketing Theory and Practice, Vol. 19 No. 2, pp. 221-234.

Arndt, J. (1967), "Word-of-mouth advertising and informal communication”, in Cox, D.F. (Ed.), Risk-Taking and Information-Handling in Consumer Behavior, Harvard University Press, Boston, pp. 188-239.

Armstrong, J.S. and Overton, T.S. (1977), "Estimating nonresponse bias in mail surveys", Journal of Marketing Research, Vol. 14 No. 3, pp. 396-402.

Aronson, E. (1992), “The return of the repressed: Dissonance theory makes a comeback”, Psychological Inquiry, Vol. 3 No. 4, pp. 303-311.

Babin, B.J. and Kim, K. (2001), "International students' travel behavior: a model of the travelrelated consumer/dissatisfaction process", Journal of Travel \& Tourism Marketing, Vol. 10 No. 1, pp. 93-106.

Bagozzi, R.P. and Yi, Y. (1988), "On the evaluation of structural equation models”, Journal of the Academy of Marketing Science, Vol. 16 No. 1, pp. 74-94.

Bawa, K. (1990), “Modeling inertia and variety seeking tendencies in brand choice behavior", Marketing Science, Vol. 9 No. 3, pp. 263-278.

Bloemer, J., De Ruyter, K.O. and Wetzels, M. (1999), "Linking perceived service quality and service loyalty: a multi-dimensional perspective”, European Journal of Marketing, Vol. 33 No. 11/12, pp. 1082-1106.

Bolton, R.N. (1998), "A dynamic model of the duration of the customer's relationship with a continuous service provider: The role of satisfaction", Marketing Science, Vol. 17 No 1, pp. 45-65.

Bolton, R.N. and Drew, J.H. (1991), “A multistage model of customers” assessments of service quality and value", Journal of Consumer Research, Vol. 17 No. 4, pp. 375-384.

Bolton, R.N. and Lemon, K.N. (1999), “A dynamic model of customers' usage of services: Usage as an antecedent and consequence of satisfaction", Journal of Marketing Research, Vol. 36 No. 2, pp. 171-186. 
Boulding, W., Kalra, A., Staelin, R. and Zeithaml, V.A. (1993), “A dynamic process model of service quality: From expectations to behavioral intentions”, Journal of Marketing Research, Vol. 30 No. 1, pp. 7-27.

Brady, M.K. and Robertson, C.J. (2001), "Searching for a consensus on the antecedent role of service quality and satisfaction: an exploratory cross-national study", Journal of Business Research, Vol. 51 No. 1, pp. 53-60.

Brady, M.K., Cronin Jr, J.J. and Brand, R.R. (2002), "Performance-only measurement of service quality: a replication and extension”, Journal of Business Research, Vol. 55 No. 1, pp. 1731.

Brown, T.J., Barry, T.E., Dacin, P.A. and Gunst, R.F. (2005), "Spreading the word: Investigating antecedents of consumers' positive word-of-mouth intentions and behaviors in a retailing context", Journal of the Academy of Marketing Science, Vol. 33 No. 2, pp. 123-138.

Carpenter, J.M. and Fairhurst, A. (2005), "Consumer shopping value, satisfaction, and loyalty for retail apparel brands", Journal of Fashion Marketing and Management, Vol. 9 No. 3, pp. 256-269.

Caruana, A., Money, A.H. and Berthon, P.R. (2000), "Service quality and satisfaction-the moderating role of value", European Journal of Marketing, Vol. 34 No. 11/12, pp. 13381353.

Caruana, A. (2002), "Service loyalty: the effects of service quality and the mediating role of customer satisfaction", European Journal of Marketing, Vol. 36 No. 7/8, pp. 811-828.

Chiou, J.S., Droge, C. and Hanvanich, S. (2002), "Does customer knowledge affect how loyalty is formed?", Journal of Service Research, Vol. 5 No. 2, pp. 113-124.

Cialdini, R.B. (1993), Influence: The psychology of Persuasion, Morrow, New York.

Colgate, M. and Lang, B. (2001), "Switching barriers in consumer markets: an investigation of the financial services industry", Journal of Consumer Marketing, Vol. 18 No. 4, pp. 332347.

Converse, P.E. (1995), "Foreword", in Petty, R.E. and Kronsnick, J.A. (Eds.), Attitude Strength: Antecedents and Consequences, Lawrence Erlbaum, Mahwah, NJ, pp. xi-xvii.

Cooil, B., Keiningham, T.L., Aksoy, L. and Hsu, M. (2007), “A longitudinal analysis of customer satisfaction and share of wallet: Investigating the moderating effect of customer characteristics", Journal of Marketing, Vol. 71 No. 1, pp. 67-83. 
Cronin Jr, J.J. and Taylor, S.A. (1992), "Measuring service quality: a reexamination and extension”, Journal of Marketing, Vol. 56 No. 3, pp. 55-68.

Cronin Jr, J.J., Brady, M.K. and Hult, G.T.M. (2000), “Assessing the effects of quality, value, and customer satisfaction on consumer behavioral intentions in service environments", Journal of Retailing, Vol. 76 No. 2, pp. 193-218.

Dabholkar, P.A., Shepherd, C.D. and Thorpe, D.I. (2000), “A comprehensive framework for service quality: an investigation of critical conceptual and measurement issues through a longitudinal study", Journal of Retailing, Vol. 76 No. 2, pp. 139-173.

Davidow, M. (2003), "Have you heard the word? The effect of word of mouth on perceived justice, satisfaction and repurchase intentions following complaint handling", Journal of Consumer Satisfaction Dissatisfaction and Complaining Behavior, Vol. 16, No. 3, pp. 6780.

de Matos, C.A. and Rossi, C.A.V. (2008), "Word-of-mouth communications in marketing: A meta-analytic review of the antecedents and moderators", Journal of the Academy of Marketing Science, Vol. 36 No. 4, pp. 578-596.

Dick, A.S. and Basu, K. (1994), "Customer loyalty: toward an integrated conceptual framework", Journal of the Academy of Marketing Science, Vol. 22 No. 2, pp. 99-113.

Diep, V.C.S. and Sweeney, J.C. (2008), “Shopping trip value: do stores and products matter?”, Journal of Retailing and Consumer Services, Vol. 15 No. 5, pp. 399-409.

Dodds, W.B. and Monroe, K.B. (1985), "The effect of brand and price information on subjective product evaluations", Advances in Consumer Research, Vol. 12 No. 1, pp. 85-90.

Duhigg, C. (2012), The Power of Habit: Why We Do What We Do In Life and Business, Random House, New York.

Durvasula, S., Lysonski, S., Mehta, S.C. and Tang, B.P. (2004), "Forging relationships with services: the antecedents that have an impact on behavioural outcomes in the life insurance industry", Journal of Financial Services Marketing, Vol. 8 No. 4, pp. 314-326.

Espejel, J., Fandos, C. and Flavián, C. (2007),"The role of intrinsic and extrinsic quality attributes on consumer behaviour for traditional food products", Managing Service Quality: An International Journal, Vol. 17 No 6, pp. 681-701.

Evanschitzky, H. and Wunderlich, M. (2006), “An examination of moderator effects in the fourstage loyalty model”, Journal of Service Research, Vol. 8 No. 4, pp. 330-345. 
Faullant, R., Matzler, K. and Füller, J. (2008),"The impact of satisfaction and image on loyalty: the case of Alpine ski resorts", Managing Service Quality: An International Journal, Vol. 18 No 2 pp. 163-178.

Fornell, C., Johnson, M.D., Anderson, E.W., Cha, J. and Bryant, B.E. (1996), "The American customer satisfaction index: Nature, purpose, and findings", Journal of Marketing, Vol. 60 No. 4, pp. 7-18.

Ganesh, J., Arnold, M.J. and Reynolds, K.E. (2000), "Understanding the customer base of service providers: an examination of the differences between switchers and stayers", Journal of Marketing, Vol. 64 No. 3, pp. 65-87.

Garbarino, E. and Johnson, M.S. (1999), “The different roles of satisfaction, trust, and commitment in customer relationships", Journal of Marketing, Vol. 63 No. 2, pp. 70-87.

Garnefeld, I., Eggert, A., Helm, S.V. and Tax, S.S. (2013), 'Growing existing customers' revenue streams through customer referral programs", Journal of Marketing, Vol. 77 No. 4, pp. 17-32.

Gawronski, B. and Bodenhausen, G.V. (2006), “Associative and propositional processes in evaluation: an integrative review of implicit and explicit attitude change", Psychological Bulletin, Vol. 132 No. 5, pp. 692-731.

Gounaris, S. and Stathakopoulos, V. (2004), “Antecedents and consequences of brand loyalty: an empirical study", The Journal of Brand Management, Vol.11 No.4, pp. 283-306.

Greenwald, A.G. and Banaji, M.R. (1995), "Implicit social cognition: attitudes, self-esteem, and stereotypes", Psychological Review, Vol. 102 No. 1, pp. 4-27.

Gruen, T.W., Osmonbekov, T. and Czaplewski, A.J. (2006), “eWOM: The impact of customerto-customer online know-how exchange on customer value and loyalty", Journal of Business Research, Vol. 59 No. 4, pp. 449-456.

Gustafsson, A., Johnson, M.D. and Roos, I. (2005) “The effects of customer satisfaction, relationship commitment dimensions, and triggers on customer retention", Journal of Marketing, Vol. 69 No. 4, pp. 210-218.

Hair, J.F., Jr., Hult, G.T.M., Ringle, C.M. and Sarstedt, M. (2014), A Primer on Partial Least Squares Structural Equation Modeling (PLS-SEM), SAGE Publications, Thousand Oaks, CA. 
Hair, J.F., Jr., Ringle, C.M. and Sarstedt, M. (2011), "PLS-SEM: Indeed a silver bullet”, Journal of Marketing Theory and Practice, Vol. 19 No. 2, pp. 139-151.

Hair, J.F., Black, W.C., Babin, B.J., Anderson, R.E. and Tatham, R.L. (2006), Multivariate Data Analysis (Vol. 6), Pearson Prentice Hall, Upper Saddle River, NJ.

Han, H., Kim, Y. and Kim, E.K. (2011), “Cognitive, affective, conative, and action loyalty: Testing the impact of inertia", International Journal of Hospitality Management, Vol. 30 No. 4, pp. 1008-1019.

Harris, L.C. and Goode, M.M. (2004), "The four levels of loyalty and the pivotal role of trust: a study of online service dynamics", Journal of Retailing, Vol. 80 No. 2, pp. 139-158.

Harrison-Walker, L.J. (2001), "The measurement of word-of-mouth communication and an investigation of service quality and customer commitment as potential antecedents", Journal of Service Research, Vol. 4 No. 1, pp. 60-75.

Hartline, M.D. and Jones, K.C. (1996), "Employee performance cues in a hotel service environment: influence on perceived service quality, value, and word-of-mouth intentions", Journal of Business Research, Vol. 35 No. 3, pp. 207-215.

Hennig-Thurau, T. and Klee, A. (1997), "The impact of customer satisfaction and relationship quality on customer retention: A critical reassessment and model development", Psychology \& Marketing, Vol. 14 No. 8, pp. 737-764.

Henseler, J., Ringle, C.M. and Sinkovics, R.R. (2009), "The use of partial least squares path modeling in international marketing", Advances in International Marketing, Vol. 20 No. 1, pp. 277-319.

Henseler, J. and Fassott, G. (2010), “Testing moderating effects in PLS path models: an illustration of available procedures", in Esposito V.V., Chin, W.W., Henseler, J., Wang, H. (Eds.). Handbook of Partial Least Squares: Concepts, Methods and Applications, Springer, Heidelberg, pp. 713-735.

Homburg, C. and Giering, A. (2001), "Personal characteristics as moderators of the relationship between customer satisfaction and loyalty - an empirical analysis", Psychology \& Marketing, Vol. 18 No. 1, pp. 43-66.

Homburg, C., Koschate, N. and Hoyer, W.D. (2005), "Do satisfied customers really pay more? A study of the relationship between customer satisfaction and willingness to pay", Journal of Marketing, Vol. 69 No. 2, pp. 84-96. 
Huang, M.H. and Yu, S. (1999), “Are consumers inherently or situationally brand loyal? - A set intercorrelation account for conscious brand loyalty and nonconscious inertia", Psychology \& Marketing, Vol. 16 No. 6, pp. 523-544.

Ittner, C.D. and Larcker, D.F. (1998), “Are nonfinancial measures leading indicators of financial performance? An analysis of customer satisfaction", Journal of Accounting Research, Vol. 36 (supplement), pp. 1-35.

Jayawardhena, C., Morrell, K. and Stride, C. (2016), "Ethical consumption behaviours in supermarket shoppers: determinants and marketing implications", Journal of Marketing Management, DOI:10.1080/0267257X.2015.1134627.

Ji Song, M.F. and Wood, W. (2007), "Purchase and consumption habits: Not necessarily what you intend", Journal of Consumer Psychology, Vol. 17 No. 4, pp. 261-276.

Johnson, M.D. and Fornell, C. (1991), “A framework for comparing customer satisfaction across individuals and product categories”, Journal of Economic Psychology, Vol. 12 No. 2, pp. $267-286$.

Johnson, M.D., Anderson, E.W. and Fornell, C. (1995), "Rational and adaptive performance expectations in a customer satisfaction framework", Journal of Consumer Research, Vol. 21, No. 4, 695-707.

Jones, M.A. and Reynolds, K.E. (2006), "The role of retailer interest on shopping behavior", Journal of Retailing, Vol. 82 No. 2, pp. 115-126.

Juga, J., Juntunen, J. and Grant, D.B. (2010), 'Service quality and its relation to satisfaction and loyalty in logistics outsourcing relationships", Managing Service Quality: An International Journal, Vol. 20 No 6 pp. 496-510.

Keiningham. T.L., Cooil, B., Aksoy, L., Andreassen, T.W. and Weiner, J. (2007),'The value of different customer satisfaction and loyalty metrics in predicting customer retention, recommendation, and share-of-wallet”, Managing Service Quality: An International Journal, Vol. 17 No 4, pp. 361-384.

Kenny, D.A. and Judd, C.M. (1984), "Estimating the nonlinear and interactive effects of latent variables", Psychological Bulletin, Vol. 96 No. 1, pp. 201-210.

Kuhl, J. and Beckmann, J. (1985), "Historical perspectives in the study of action control”, in Kuhl, J. and Beckmann, J. (Eds.), Action Control: From Cognition to Behavior, SpringerVerlag, Berlin, pp. 89-100. 
Kumar, V., Pozza, I.D. and Ganesh, J. (2013), "Revisiting the satisfaction-loyalty relationship: empirical generalizations and directions for future research", Journal of Retailing, Vol. 89 No. 3, pp. 246-262.

Kuo, Y.F., Hu, T.L. and Yang, S.C. (2013),"'Effects of inertia and satisfaction in female online shoppers on repeat-purchase intention", Managing Service Quality: An International Journal, Vol. 23 No 3, pp. 168-187.

Lally, P., Van Jaarsveld, C.H., Potts, H.W. and Wardle, J. (2010), "How are habits formed: Modelling habit formation in the real world", European Journal of Social Psychology, Vol. 40 No. 6, pp. 998-1009.

Lee, M. and Cunningham, L.F. (2001), “A cost/benefit approach to understanding service loyalty”, Journal of Services Marketing, Vol. 15 No. 2, pp. 113-130.

Lee, R. and Neale, L. (2012), "Interactions and consequences of inertia and switching costs", Journal of Services Marketing, Vol. 26 No. 5, pp. 365-374.

Liang, H., Saraf, N., Hu, Q. and Xue, Y. (2007), “Assimilation of enterprise systems: the effect of institutional pressures and the mediating role of top management”, MIS Quarterly, Vol. 31 No. 1, pp. 59-87.

Lin, J.S.C. and Wu, C.Y. (2011),"The role of expected future use in relationship-based service retention", Managing Service Quality: An International Journal, Vol. 21 No 5, pp. 535551.

Liu-Thompkins, Y. and Tam, L. (2013), "Not all repeat customers are the same: Designing effective cross-selling promotion on the basis of attitudinal loyalty and habit", Journal of Marketing, Vol. 77 No. 5, pp. 21-36.

Maxham, J.G., III and Netemeyer, R.G. (2002), “A longitudinal study of complaining customers' evaluations of multiple service failures and recovery efforts", Journal of Marketing, Vol. 66 No. 4, pp. 57-71.

Mazzarol, T., Sweeney, J.C. and Soutar, G.N. (2007), "Conceptualizing word-of-mouth activity, triggers and conditions: an exploratory study", European Journal of Marketing, Vol. 41 No. 11/12, pp. 1475-1494.

McKee, D., Simmers, C.S. and Licata, J. (2006), "Customer self-efficacy and response to service", Journal of Service Research, Vol. 8 No. 3, pp. 207-220. 
Mittal, V. and Kamakura, W.A. (2001), "Satisfaction, repurchase intent, and repurchase behavior: investigating the moderating effect of customer characteristics", Journal of Marketing Research, Vol. 38 No. 1, pp. 131-142.

Nyer, P.U. and Gopinath, M. (2005), "Effects of complaining versus negative word of mouth on subsequent changes in satisfaction: The role of public commitment", Psychology \& Marketing, Vol. 22 No. 12, pp. 937-953.

Oliver, R.L. (1993), “Cognitive, affective and attributes of the satisfaction response”, Journal of Consumer Research, Vol. 20 No. 2, pp. 418-430.

Oliver, R.L. (1999), “Whence consumer loyalty?”, Journal of Marketing, Vol. 63 No. 4, pp. 3344.

Parasuraman, A., Zeithaml, V.A. and Berry, L.L. (1988), "SERVQUAL: A multiple-item scale for measuring consumer perceptions of service quality", Journal of Retailing, Vol. 64 No. 1, pp. 12-37.

Parasuraman, A., Zeithaml, V.A. and Berry, L.L. (1994), "Reassessment of expectations as a comparison standard in measuring service quality: implications for further research", Journal of Marketing, Vol. 58 No. 1, pp. 111-124.

Podsakoff, P.M., MacKenzie, S.B., Lee, J.Y. and Podsakoff, N.P. (2003), “Common method biases in behavioral research: a critical review of the literature and recommended remedies", Journal of Applied Psychology, Vol. 88 No. 5, pp. 879-903.

Pritchard, M.P., Havitz, M.E. and Howard, D.R. (1999), “Analyzing the commitment-loyalty link in service contexts", Journal of the Academy of Marketing Science, Vol. 27 No. 3, pp. $333-348$.

Pura, M. (2005),'Linking perceived value and loyalty in location-based mobile services”, Managing Service Quality: An International Journal, Vol. 15 No 6, pp. 509-538.

Ranaweera, C. (2007) "Are satisfied long-term customers more profitable? Evidence from the telecommunication sector", Journal of Targeting, Measurement and Analysis for Marketing, Vol. 15 No. 2, pp. 113-120.

Ranaweera, C. and Jayawardhena, C. (2014), “Talk up or criticize? Customer responses to WOM about competitors during social interactions", Journal of Business Research, Vol. 67 No. 12, pp. 2645-2656. 
Reynolds, K.E. and Arnold, M.J. (2000), "Customer loyalty to the salesperson and the store: examining relationship customers in an upscale retail context", The Journal of Personal Selling \& Sales Management, Vol. 20 No. 2, pp. 89-98.

Ringle, C., Wende, S. and Will, A. (2005), SmartPLS: Release 2.0 (beta). Retrieved June 3, 2012, from http://www.smartpls.de.

Rust, R.T. and Oliver, R.L. (1994), "Service quality: insights and managerial implication from the frontier", in Rust, R.T. and Oliver, R.L. (Eds.), Service Quality: New Directions in Theory and Practice, Sage, Thousand Oaks, CA, pp. 1-19.

Rust, R.T., Lemon, K.N. and Zeithaml, V.A. (2004), "Return on marketing: using customer equity to focus marketing strategy", Journal of Marketing, Vol. 68 No. 1, pp. 109-127.

Saha, G.C. and Theingi (2009), "Service quality, satisfaction, and behavioural intentions", Managing Service Quality: An International Journal, Vol. 19 No 3, pp. 350-372.

Sabharwal, N., Soch, H. and Kaur, H. (2010), “Are we satisfied with incompetent services? A scale development approach for service recovery", Journal of Services Research, Vol. 10 No. 1, pp. 125-142.

Sánchez-Pérez, M, Gázquez-Abad, J.C., Carrillo, G.M.M. and Sánchez-Fernández, R. (2007),'Effects of service quality dimensions on behavioural purchase intentions", Managing Service Quality: An International Journal, Vol. 17 No 2, pp. 134-151.

Sarstedt, M., Ringle, C.M., Smith, D., Reams, R. and Hair Jr., J.F. (2014), “Partial least squares structural equation modeling (PLS-SEM): A useful tool for family business researchers", Journal of Family Business Strategy, Vol. 5 No. 1, pp. 105-115.

Seiders, K., Voss, G.B., Grewal, D. and Godfrey, A.L. (2005), “Do satisfied customers buy more? Examining moderating influences in a retailing context”, Journal of Marketing, Vol. 69 No. 4, pp. 26-43.

Schmitt, P., Skiera, B. and Van den Bulte, C. (2011). Referral programs and customer value. Journal of Marketing, 75(1), 46-59.

Shankar, V., Smith, A.K. and Rangaswamy, A. (2003), "Customer satisfaction and loyalty in online and offline environments", International Journal of Research in Marketing, Vol. 20 No. 2, pp. 153-175.

Sichtmann, C. (2007), “An analysis of antecedents and consequences of trust in a corporate brand", European Journal of Marketing, Vol. 41 No. 9/10, pp. 999-1015. 
Sirdeshmukh, D., Singh, J. and Sabol, B. (2002), "Consumer trust, value, and loyalty in relational exchanges", Journal of Marketing, Vol. 66 No. 1, pp. 15-37.

Srinivasan, S.S., Anderson, R. and Ponnavolu, K. (2002), “Customer loyalty in e-commerce: an exploration of its antecedents and consequences”, Journal of Retailing, Vol. 78 No. 1, pp. $41-50$.

Sweeney, J.C. and Soutar, G.N. (2001), “Consumer perceived value: the development of a multiple item scale", Journal of Retailing, Vol. 77 No. 2, pp. 203-220.

Sweeney, J.C., Soutar, G.N. and Johnson, L.W. (1999), "The role of perceived risk in the quality-value relationship: a study in a retail environment", Journal of Retailing, Vol. 75 No.1, pp. 77-105.

Sweeney, J.C., Soutar, G.N. and Mazzarol, T. (2012), "Word of mouth: measuring the power of individual messages", European Journal of Marketing, Vol. 46 No. 1/2, pp. 237-257.

Söderlund, M. (2006), "Measuring customer loyalty with multi-item scales—a case for caution", International Journal of Service Industry Management, Vol. 17 No. 1, pp. 76-98.

Tam, L., Wood, W. and Ji Song, M. (2009), "Brand loyalty is not habitual," in Maclnnis, D. J., Park, C.W. and Priester, J.R. (Eds.), Handbook of Brand Relationships, M.E. Sharpe, Armonk, NY, pp. 43-62.

Uncles, M.D., Dowling, G.R. and Hammond, K. (2003), "Customer loyalty and customer loyalty programs", Journal of Consumer Marketing, Vol. 20 No. 4, pp. 294-316.

Verhoef, P.C. (2003), "Understanding the effect of customer relationship management efforts on customer retention and customer share development", Journal of Marketing, Vol. 67 No. 4, pp. 30-45.

Verhoef, P.C., Franses, P.H. and Hoekstra, J.C. (2002), “The effect of relational constructs on customer referrals and number of services purchased from a multiservice provider: does age of relationship matter?", Journal of the Academy of Marketing Science, Vol. 30 No. 3, pp. 202-216.

Vogel, V., Evanschitzky, H. and Ramaseshan, B. (2008), “Customer equity drivers and future sales", Journal of Marketing, Vol. 72 No. 6, pp. 98-108.

Wangenheim, F.V. and Bayón, T. (2007), "The chain from customer satisfaction via word-ofmouth referrals to new customer acquisition", Journal of the Academy of Marketing Science, Vol. 35 No. 2, pp. 233-249. 
Watson, G.F., Beck, J.T., Henderson, C.M. and Palmatier, R.W. (2015), "Building, measuring, and profiting from customer loyalty", Journal of the Academy of Marketing Science, Vol. 43 No. 4, pp 790-825.

Westbrook, R.A. (1987), "Product/consumption-based affective responses and postpurchase processes", Journal of Marketing Research, Vol. 24 No. 3, pp. 258-270.

White, L. and Yanamandram, V. (2004),'Why customers stay: reasons and consequences of inertia in financial services", Managing Service Quality: An International Journal, Vol. 14 No 2/3, pp. 183-194.

Wien, A.H. and Olsen, S.O. (2012), "Evaluation context's role in driving positive word-of-mouth intentions", Journal of Consumer Behaviour, Vol. 11 No. 6, pp. 504-513.

Wilson, T.D., Lindsey, S. and Schooler, T.Y. (2000), “A model of dual attitudes”, Psychological Review, Vol. 107 No. 1, pp. 101-126.

Wirtz, J. and Chew, P. (2002), "The effects of incentives, deal proneness, satisfaction and tie strength on word-of-mouth behavior”, Journal of Service Management, Vol. 13 No 2, pp. $141-162$.

Wood, W. and Neal, D.T. (2009), "The habitual consumer”, Journal of Consumer Psychology, Vol. 19 No. 4, pp. 579-592.

Wood, W., Tam, L. and Witt, M.G. (2005), "Changing circumstances, disrupting habits", Journal of Personality and Social Psychology, Vol. 88 No. 6, pp. 918-933.

Wu, L.W. (2011), "Satisfaction, inertia, and customer loyalty in the varying levels of the zone of tolerance and alternative attractiveness", Journal of Services Marketing, Vol. 25 No. 5, pp. $310-322$.

Yanamandram, V. and White, L. (2006), "Switching barriers in business-to-business services: A qualitative study", International Journal of Service Industry Management, Vol. 17 Vol. 2, pp. $158-192$.

Yang, Z. and Peterson, R.T. (2004), "Customer perceived value, satisfaction, and loyalty: the role of switching costs", Psychology \& Marketing, Vol. 21 No. 10, pp. 799-822.

Yen, C.H. and Lu, H.P. (2008), "Effects of e-service quality on loyalty intention: an empirical study in online auction", Managing Service Quality: An International Journal, Vol. 18 No. 2 pp. $127-146$. 
Zeelenberg, M. and Pieters, R. (2004), "Beyond valence in customer dissatisfaction: A review and new findings on behavioral responses to regret and disappointment in failed services", Journal of Business Research, Vol. 57 No. 4, pp. 445-455.

Zeithaml, V.A. (1988), "Consumer perceptions of price, quality, and value: a means-end model and synthesis of evidence", Journal of Marketing, Vol. 52 No. 3, pp. 2-22.

Zeithaml, V.A., Berry, L.L. and Parasuraman, A. (1996), "The behavioral consequences of service quality", Journal of Marketing, Vol. 60 No. 2, pp. 31-46. 
List of Figures

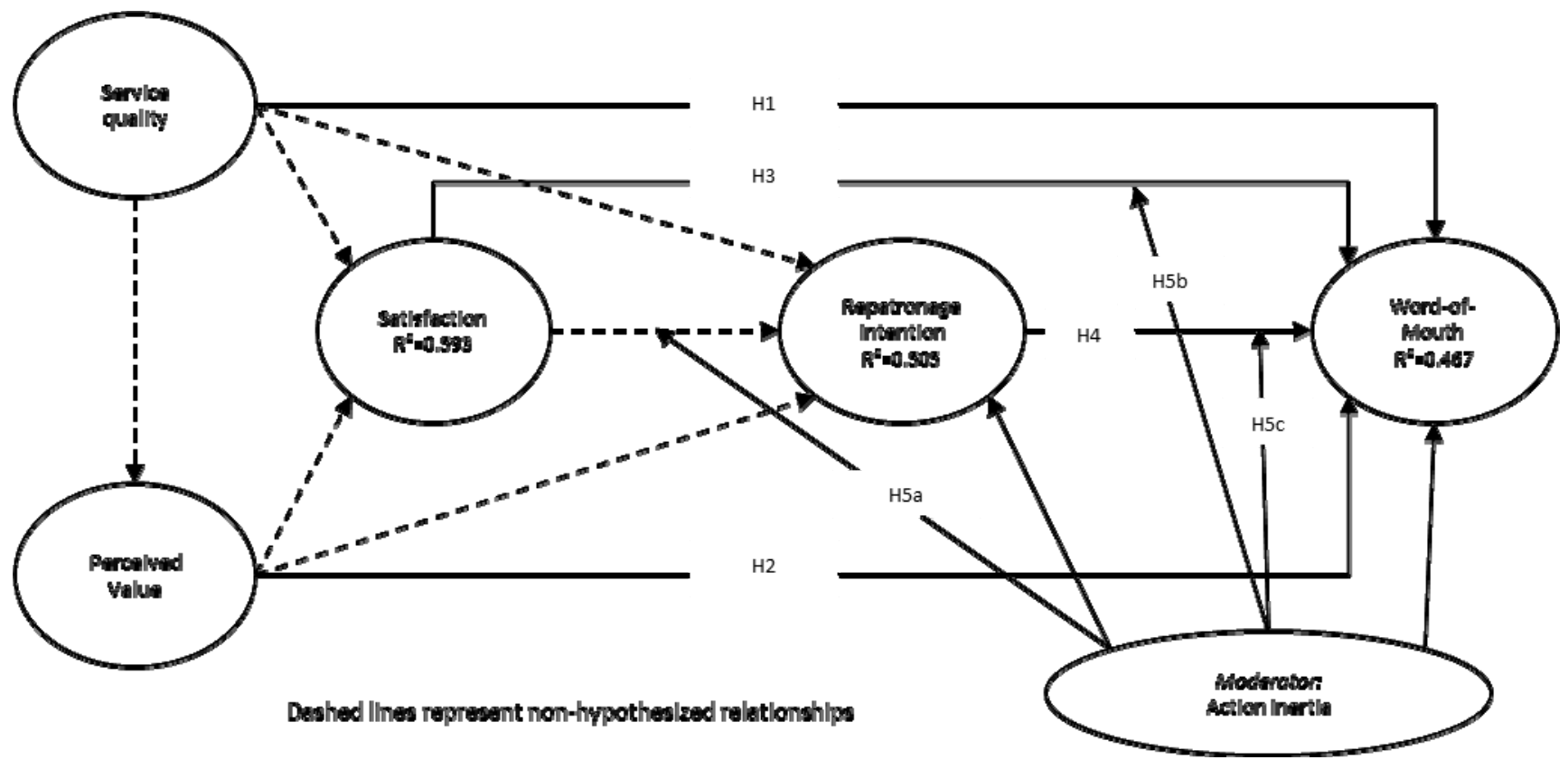

Fig. 1. Conceptual model. 


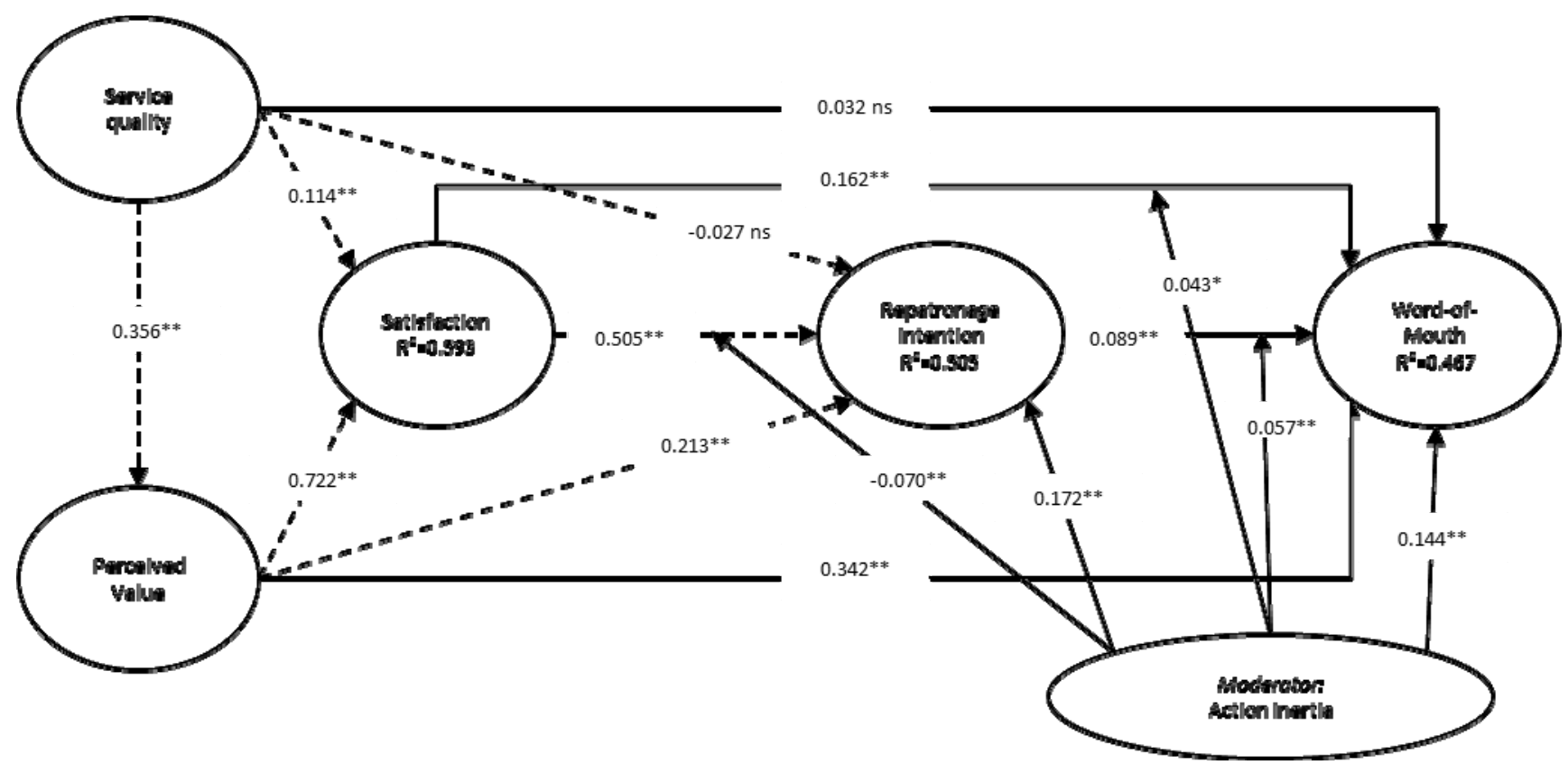

Fig. 2. Path model and PLS-SEM estimates. Dashed lines represent non-hypothesized relationships. $* * p<0.01,{ }^{*} p$ $<0.05 ; \mathrm{ns}=$ non-significant.

\section{List of Tables}

Table 1

Discriminant validity.

\begin{tabular}{|c|c|c|c|c|c|c|c|c|c|c|c|}
\hline & 1 & 2 & 3 & 4 & 5 & 6 & 7 & 8 & 9 & 10 & 11 \\
\hline 1. Service quality & 0.725 & & & & & & & & & & \\
\hline 2. Perceived value & 0.355 & 0.756 & & & & & & & & & \\
\hline
\end{tabular}




\begin{tabular}{|c|c|c|c|c|c|c|c|c|c|c|c|}
\hline 3. Satisfaction & 0.372 & 0.749 & 0.815 & & & & & & & & \\
\hline 4. Repatronage intention & 0.247 & 0.608 & 0.677 & 0.897 & & & & & & & \\
\hline 5. WOM & 0.278 & 0.645 & 0.611 & 0.509 & 0.953 & & & & & & \\
\hline 6. Action inertia & 0.293 & 0.735 & 0.747 & 0.604 & 0.585 & 0.836 & & & & & \\
\hline 7. Consumption & -0.056 & -0.107 & -0.110 & -0.094 & -0.028 & -0.090 & n.a. & & & & \\
\hline 8. Gender & -0.176 & -0.026 & -0.041 & -0.034 & -0.026 & -0.031 & -0.032 & n.a. & & & \\
\hline 9. Age & -0.046 & 0.095 & 0.056 & 0.084 & 0.072 & 0.071 & -0.031 & 0.067 & n.a. & & \\
\hline 10. Income & -0.094 & -0.159 & -0.095 & -0.067 & -0.121 & -0.077 & 0.117 & 0.236 & 0.257 & n.a. & \\
\hline 11. Relationship age & 0.038 & 0.045 & 0.046 & 0.190 & 0.078 & 0.036 & 0.067 & 0.014 & 0.151 & 0.063 & n.a. \\
\hline $\bar{M}$ & 5.73 & 4.93 & 5.09 & 5.42 & 4.39 & 4.79 & - & - & - & - & - \\
\hline SD & 1.32 & 1.93 & 1.32 & 1.51 & 1.75 & 1.35 & - & - & - & - & - \\
\hline
\end{tabular}

Note: The square root of the AVE is on the diagonal (in bold). Inter-construct correlations are off-diagonal. n.a: not applicable.

\section{Appendix A. Construct measures and indicator loadings}

Measures $^{\mathrm{a}}$
Service quality $(\mathrm{CR}=0.961 ; \mathrm{AVE}=0.525)$
Please indicate how important each of the following is when buying telecommunications
services:

Please indicate how important each of the following is when buying telecommunications services: 
Providing services as promised

$\begin{array}{ll}\text { Dependability in handling customers' service problems } & 0.826\end{array}$

$\begin{array}{lr}\text { Performing services right the first time } & 0.834\end{array}$

$\begin{array}{lr}\text { Providing services at the promised time } & 0.824\end{array}$

Keeping customers informed about when services will be performed $\quad 0.812$

$\begin{array}{lr}\text { Prompt service to customers } & 0.879\end{array}$

$\begin{array}{ll}\text { Employees who are always willing to help customers } & 0.848\end{array}$

Employees who are not too busy to respond to customer request promptly 0.890

$\begin{array}{ll}\text { Employees who are trustworthy } & 0.801\end{array}$

The feeling that you are safe when conducting transactions with the company $\quad 0.834$

$\begin{array}{ll}\text { Employees who are polite } & 0.887\end{array}$

$\begin{array}{ll}\text { Employees who have the knowledge to answer customer questions } & 0.827\end{array}$

$\begin{array}{lr}\text { Individual attention } & 0.834\end{array}$

$\begin{array}{ll}\text { Employees who give you personal attention } & 0.895\end{array}$

$\begin{array}{lr}\text { A firm that has your best interests at heart } & 0.916\end{array}$

$\begin{array}{ll}\text { Employees who know what your needs are } & 0.901\end{array}$

$\begin{array}{ll}\text { Visually appealing pages are used } & 0.823\end{array}$

$\begin{array}{ll}\text { Modern design and graphics are used } & 0.801\end{array}$

$\begin{array}{ll}\text { The website is well designed and has a professional appearance } & 0.914\end{array}$

$\begin{array}{ll}\text { The website is visually appealing } & 0.885\end{array}$

$\begin{array}{ll}\text { The website is easily accessible } & 0.879\end{array}$

$\begin{array}{ll}\text { Website provides useful information to answer customer questions } & 0.838\end{array}$

Perceived value $(\mathrm{CR}=0.941 ; \mathrm{AVE}=0.571)$

Please indicate your level of agreement with the following statements:

Services are reasonably priced

Are good services for the price 
Satisfaction $(\mathrm{CR}=0.908 ; \mathrm{AVE}=0.665)$

Please indicate your level of agreement with the following statements:

I like using the services.

The services have met my expectations.

Repatronage intentions $(\mathrm{CR}=0.925 ; \mathrm{AVE}=0.804)$

Please indicate your level of agreement with the following statements:

I consider myself a loyal customer of company X.

Action inertia $(\mathrm{CR}=0.873 ; \mathrm{AVE}=0.699)$

Please indicate your level of agreement with the following statements:

I have repeatedly found company $\mathrm{X}$ is better than others. 
Positive $W O M(\mathrm{CR}=0.952 ; \mathrm{AVE}=0.804)$

Please indicate your level of agreement with the following statements:

Say positive things about company $\mathrm{X}$ to other people

Recommend company $\mathrm{X}$ to someone who seeks your advice

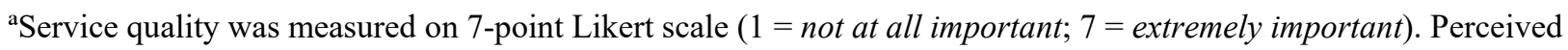
value, satisfaction, repatronage intentions, action inertia, and positive WOM were measured on 7-point Likert scales $(1=$ strongly disagree; 7 = strongly agree $)$.

Note: $\mathrm{CR}=$ composite reliability. 